\title{
Application of Psychological Scene Drama in College Psychology Teaching
}

\author{
Qingming Liu \\ Wuhan Textile University, Wuhan Hubei, 430073, China
}

Keywords: Psychological scene drama, College students, Psychology, Application.

\begin{abstract}
The application of psychological scene drama in teaching college students psychology can significantly stimulate students' class participation enthusiasm, effectively deepen understanding of students' psychological health problem, promote exertion of psychology teaching function and lay a solid foundation for training students' comprehensive quality. This paper starts from connotation and features of psychological scene drama and analyzes its specific application, in the hope of offering corresponding support and reference for college psychology teaching.
\end{abstract}

\section{Introduction}

Psychological scene drama has certain advantage in psychology teaching for college students. Students can highly approve psychological scene drama in the process of participating in psychological scene drama and then accept corresponding education guidance in the participation process. This can offer certain help for students to learn psychology. Simply speaking, psychological scene drama handles psychological problems in the form of team drama performance. Generally, the visitors express their confusion through psychological scene drama. Then, the therapist guides them according to actual conditions, solves their psychological problems and promotes them to improves their insight and judgment. But, current application of psychological scene drama in college psychology teaching is not extensive enough. The function of psychological scene drama in teaching cannot be fully exerted. Thus, this paper analyzes the application of psychological scene drama in college psychology teaching and expects to provide corresponding assistance for popularizing and applying psychological scene drama as well as improving college psychology teaching quality.

\section{Basic connotation of campus psychological scene drama}

Campus psychological scene drama originally derived from "psychodrama”. It further develops psychodrama in education field. In 1980s, psychodrama spread internationally and was introduced in China gradually. It has generated certain influence on the research on psychological counseling and psychological education. As Chinese scholars study psychodrama and it is practically applied in psychology field and education field, psychological scene drama appears. Based on Chinese native couture and basic national conditions, psychological scene drama overall absorbs art essence of psychodrama, social drama, dance art, music and drawing in the development process, and forms action expression performance art with strong local features in the application of psychological scene drama in psychological health education field ${ }^{[1]}$. Generally, the main form of psychological scene drama is stage performance. It can avoid infusion of dull psychology knowledge in teaching practice to some extent and facilitates significant improvement of visibility and interaction of psychology theory teaching. In current campus education activity, psychological scene drama generally originates from real life of college students. The specific contents include interpersonal relationship handling of college students, self-awareness growth, emotion management and school work development etc., and can vividly reflect psychological conflict, confusion and anxiety of college students in the growing process. Students as the actors and audiences can carry out autocriticism and self-education in the actual performance and appreciation process. It really achieves teaching in the drama. Hence, psychological scene drama plays a great helping role in psychology teaching. Therefore, the application of psychological scene drama in college psychology teaching has certain applicability and necessity. It deserves further exploration and research. 


\section{Main features of psychological scene drama}

Psychological scene drama plays a great helping role in college psychology teaching. The realization of such helping role is closely related to its main features. Next, this paper analyzes main features of psychological scene drama in detail.

\section{Subjectivity.}

Based on modern education thought, respecting the dominant status in college psychology teaching has been an important education principle. In psychological scene drama, students as the participation subjects accomplish corresponding theme tasks under the guidance and help of teachers and then self-direct and act in the whole process of scene drama. It thus can be seen that, in the whole process from scene drama writing to final performance, students' dominant status can be respected. Besides, students can give full play to their creativity and imagination in actual performance process through blending in the dominant role. Then, students' learning consciousness, initiative and enthusiasm can be effectively mobilized ${ }^{[2]}$. It thus can be seen that, the practical application of psychological scene drama in psychology teaching can overall break through traditional classroom idea dominated by teaching explanation. Based on maintaining students' subjectivity, classroom teaching effect can be fully exerted.

\section{Experience property.}

Experience property is another important features of psychological scene drama. From the perspective of psychology, experience is true feeling for things and profound understanding of experience subjects. On this basis, experience subjects generate corresponding emotion and generate significance. On this basis, in the performance of psychological scene drama, every participant can generate certain emotional feeling in relatively true situation, regardless of actual performers or audiences. Further, they gain ideological enlightenment. Meanwhile, appropriate emotional experience activity can effectively motivate psychological internalization mechanism of students and offer corresponding assistance for students' psychological construction ${ }^{[3]}$. Thus, in psychological scene drama, the story experience in the drama will fuse with psychological structure of college students in the process of participating in and appreciating psychological scene drama. Then, students' knowledge structure, emotional experience and values change. The adjustment and transformation of students' psychology is completed through the force of scene drama. Conditions are created for healthy growth of students' psychology.

\section{Generation property.}

Psychology teaching for college students based on psychological scene drama can reflect unforeseeable teaching factors and the information which influences teaching situation in teaching activity under the precondition of elastic presupposition. Generative teaching resources are fully utilized for self-construction of teaching activity. Fusion of psychological scene drama in college psychology teaching can further enhance particular emphasis on expressive teaching goal of psychology teaching and contribute to expansion of teaching field. In teaching practice, every relevant psychological scene drama subject can create certain teaching situation for students, specify the problems to be solved and the objective, focus on individualized performance in classroom learning and attach importance to gain personal growth significance. it thus can be seen that, psychological scene drama has certain generation feature and can positively influence implementation of college psychology teaching.

\section{Application of psychological scene drama in college psychology teaching}

\section{Application advantage of psychological scene drama in classroom teaching practice.}

In college psychology teaching, although the story plot of psychological scene drama is relatively simple, it owns intensive conflicts, and the story plot generally comes from students' daily life, so students can be attracted to participate and view. It has significant effect on students' psychological health education and owns certain application advantages. 
1) Enrich classroom teaching and further motivate students' learning interest and thirst for knowledge

Due to the influence of new course teaching concept, college course setting mainly involves required and optimal courses, which reflects persistence in academic freedom, learning freedom to some extent and contributes to forming individualized life view and values in learning process and generates corresponding positive influence students' individual knowledge structure construction. College students are in the key period of growth and development. Their physical and mental development gradually tends to be mature. In the long-term learning process, their abstract thinking ability is enhancing gradually. They can combine their learning habits to explore suitable learning methods and have certain learning autonomy and independence. But in social construction and development process, some college students are influenced by unhealthy ways and customs, and the tendency that "it is useless to learn" occurs in their thought. Some college students even consider they are satisfied as long as they can gain corresponding diploma after they graduate. Thus, they ignore professional knowledge learning, which generates certain poor influence on their integrated development. For the students of non-psychology major, psychology is not required content. Thus, students ignore such knowledge, and their learning effect is not ideal. On this basis, the application of psychological scene drama in psychology teaching practice can further enhance artistry and interestingness of classroom teaching, then effectively motivate students' learning enthusiasm and promote them to actively participate and carefully think. Psychological scene drama has certain position influence on achievement of good teaching effect.

\section{2) Help students deeply understand teaching content}

Since some psychology knowledge is abstract, it is hard for students to deeply understand psychology knowledge, which is not beneficial to training students' psychological quality ${ }^{[4]}$. When psychological scene drama is applied in teaching practice, students can form deep perception of psychology knowledge in the process of participating in scene drama and then compelte comprehension and internalization of psychology knowledge in personal experience process. They can combine their knowledge reserve to construct individualized knowledge structure, and improve their psychology learning ability. Psychological scene drama can guide students to form correct life view and values and offer guarantee for their healthy growth.

3) Further improve students' problem solving ability

The application of psychological scene drama in psychology teaching can promote students to train their problem solving ability in the process of participating in scene drama performance. When students participate in psychological scene drama performance, they will generate large role contrast. Students can reach the state of forgetting themselves in the participation process and comprehensively understand conflicts of roles. In the process of deducing roles to solve problems, students' ability to solve problems will also be trained. It thus can be seen that, students' participation in the performance of psychological scene drama, their comprehensive strength is enhanced.

\section{Specific application of psychological scene drama in classroom teaching practice.}

Relevant researches explicitly indicate that in current stage, Chinese colleges generally blend psychological scene drama in students' extracurricular activities and implement it in the form of club or competition. It is seldom applied in psychology teaching. But based on the application advantage of psychological scene drama in psychology teaching, it is very necessary to explore the application of psychological scene drama in psychology teaching, offer corresponding assistance for psychology teaching and promote the functions of psychology teaching (such as guiding students to form correct life view and values, and promoting healthy growth of students) to be fully exerted so as to contribute to driving students' integrated development ${ }^{[5]}$. On this basis, this paper analyzes the specific operation process of applying psychological scene drama in college psychology teaching.

Firstly, in the first class hour stage, the teacher should survey the confusion and problems of students in current daily life as well as current affairs and then combine the requirements for psychology teaching proposed by teaching program to formulate certain teaching objective with practicalness and operation. On this basis, the teacher should listen to students' opinions, draft corresponding psychological scene drama themes together with students such as self-knowledge, 
interpersonal relationship in the dormitory and live, and regard these as the principal line of class teaching activities.

Secondly, students in the class are divided into several learning groups, and each group includes 8-10 members. To further improve teaching effect of psychological scene drama, the teacher can guide 2 students to compelte a drama through cooperation with the basic mode of "campus $A B$ drama" in the process of creating psychological scene program.

Thirdly, in the second class hour stage, after students finish drama design, the teacher combines the script written by students and guide them to rehearse relevant psychological scene dramas, choose some of them to let students perform and share with other students. In this link, the teacher should evaluate students' actual performance situation and score them according to the evaluation result.

Finally, the teacher should appraise the dramas performed by studnets in different classes through comparison and choose a group of excellent dramas to participate in appraisal of teaching effects of large psychological health education. Based on consolidating and popularizing teaching effects, the teacher should stimulate students' enthusiasm to create psychological scene drama through appraisal and comparison, let students take active part in drama creation, promote studnets to significantly improve their ability to learn psychology and lay a foundation for studnets to develop good psychological quality.

\section{Conclusion}

In one word, psychological scene drama has certain advantage in college psychology teaching and generates positive influence on improving psychology teaching quality, cultivating their psychological quality and intensifying volitional quality. Hence, college psychology teachers should enhance attention to psychological scene drama teaching, actively combine teaching content to apply psychological scene drama in teaching practice, let students form profound cognition of psychology knowledge in participating in scene drama performance and offer corresponding guarantee for students’ integrated development on the basis of improving teaching quality.

\section{References}

[1] Shen Wei, Application of psychological scene drama in Nursing Psychology teaching, Journal of Nurses Training, 2013,28(11):996-998.

[2] Zheng Yawei, Study on verbal humor phenomenon in situation comedy works under perspective of meme theory. Guizhou Normal University, 2014.

[3] Wu Yuling, Wang Dongrui, Study on application value of scene drama Nursing Psychology teaching, Medical Aesthetics and Beauty (II), 2015(4):196-196.

[4] Luo Hongyan, Present situation research on health education course for female college students, Modern Enterprise Education, 2014(16):262-262.

[5] Huang Li, Application of case teaching and scene simulation teaching in Nursing Psychology teaching, Medical Information, 2014(17):3-3.

[6] Zhou Zhuohong, Study on application of scene experience teaching mode in college psychology course, Vocational \& Technical Education Forum, 2014(12):83-85. 